\title{
Impact of Employee Participation on Job Satisfaction, Employee Fairness Perception and Organizational Commitment: A Case of Nepalese Commercial Banks
}

\author{
Achyut Gyawali ${ }^{1}$
}

\begin{abstract}
Bank is one of the major institutions in the financial sector of any economy. Banking sector plays a vital role as a financial intermediary in the economic development of the country. Among those factors, impact of employee participation on job satisfaction, employee fairness perception and organizational commitment, is also considered as one of the most important factors that improves the performance of commercial banks. This study deals with the fundamental issues associated with the impact of employee participation on job satisfaction, employee fairness perception and organizational commitment of commercial banks of Nepal. In selecting the most reliable and representative samples, stratified sampling techniques was used. The population of the commercial banks was stratified as joint ventures, non-joint ventures and public banks. 15 commercial banks were selected as the sample. The total number of observations used for this study is 200 which include 70 observations from the joint venture banks, 110 observations from the non-joint venture banks and 20 observations from the public banks. Impact of employee participation on job satisfaction, employee fairness perception and organizational commitment have positive significant relation. Among all three determinants organizational commitment is more influenced by employee participation as it has highest correlation coefficient. Most of the surveyed employees agreed that management gives recognition for job performance and they are satisfied with the freedom in work; every employee has opportunity to get promotion in bank, and they are willing to put in a great deal of effort beyond expected in order to help the organization to be successful.
\end{abstract}

Key words: Employee participation, Job satisfaction, Employee fairness perception and organizational commitment

\section{Introduction}

Bank is one of the major institutions in the financial sector of any economy. Banking sector plays a vital role as a financial intermediary in the economic development of the country. Among those factors, impact of employee participation on job satisfaction, employee fairness perception and organizational commitment, also considered as one of the most important factors that improves the performance of commercial banks. Employee participation is considered as a critical success factor for organizations because it enhances employee retention, increases productivity, reduces turnover, enhances loyalty, improves teamwork and

1 Associate Professor, Central Department of Management, Tribhuvan University, Kirtipur 
ultimately increases the financial performance of commercial banks (Hussain, 2010). If rules are applied fairly and consistently to all employees and if they are rewarded based on their performance and merit, then employees will perceive the evaluation process as fair. This will lead to higher organizational commitment. However, if employees perceive organizational procedures as unfair, they may take destructive actions which may lead to reduced organizational commitment. Unfair procedures will cause a reduction in organizational commitment even when an employee is satisfied with the outcome. On the other hand, employees may be dissatisfied with their outcomes, yet remain committed to an organization if they perceive procedures for their unattained outcomes to be fair (Tang and Sarsfield-Baldwin, 1996). Positive association between job satisfaction and organizational commitment is strongest for affective commitment (Mathieu and Zajac, 1990). Employees who are satisfied with their jobs may develop emotional attachments (high affective commitment) to their organizations. Participation helps management to decide in selecting the courses of action in enterprise. It gives the employee an opportunity to express their viewpoints about action. Participating in goal setting, the employees can play a vital role in achieving business target. Participation typically brings higher output and a better quality of output. It tends to improve motivation because employees feel more accepted and involved in the situation. Turnover and absences may be reduced if the employees feel that they have a better place to work (Newstrom and Davis, 2004). Job involvement and its outcomes such as job satisfaction, job commitment, and employee job performance are among the most studied areas in organizational behavior and human resource management research. Researchers showed the great interest in employee, involvement practices and their outcomes (Fenton-O'Creevy, 2001). Involvement in work and alienation from work affects the standard of one entire's life experience (Argyris, 1964). Though there are these findings in the context of different study no such findings exist on Nepalese context. Gaps in knowledge exist regarding the impact of employee participation on job satisfaction, employee fairness perception and organizational commitment at banking sector of Nepal. Hence there is a need to conduct similar studies on impact of employee participation on job satisfaction, employee fairness perception and organizational commitment in the context of Nepalese commercial banks.

Banks and financial institutions are the main stay of economic progress of a country, because the economic development highly depends upon the employee participation, extent of mobilization of resources and investment and on the operational efficiency of the various segments of the economy. Employees who are satisfied with their jobs may develop emotional attachments (high affective commitment) to their organizations (Ketchand and Strawser, 2001). Job satisfaction is, therefore, likely to be positively associated with affective organizational commitment. Employees' participation refers to the direct involvement of individuals in decisions relating to their immediate work organization and to indirect involvement in decision making, through representatives in an organization (Agrawal, 2005). And participative management is a technique in which employees are given a voice in determining what they are to do, how they are to do it, and how they are to be appraised. It is a democratic philosophy that respects all members of an organization. The concept of employees' participation in management indicates an attempt on the part of an employer to build employees into a team which works towards the realization of a common objective. It is a mental and emotional involvement of a person in a group situation which encourages them to contribute to goals 
and share responsibilities in them (Pant, 2009).

These studies focused that the employee participation is a key factor for job satisfaction, employee fairness perception and organizational commitment for improving the performance of any organization. Although banking industry in Nepal is doing remarkable progress and growth. The employee participation, fairness perception, job satisfaction and organizational commitment have been average and risks are rising. The major purpose of this study is to examine the impact of employee participation on job satisfaction, employee fairness perception and organizational commitment in the context of Nepalese banking sector.

\section{Literature Review}

Higher job satisfaction leads to higher level of organizational commitment (Allen and Meyer, 1991). Job satisfaction and employee performance of Greek banking staff revealed the use of human resources was of particular importance since this factor was the most important asset of any bank and the successful implementation of any strategic objective depends on the inspiration and hard work of the staff. A well-managed organization usually sees an average worker as the root source of quality and productivity gains. The paper investigates the problem of job satisfaction based on the results of research conducted in the Greek banking sector. Multiple theoretical frameworks regarding job satisfaction were used as the theoretical guide. The study used a descriptive survey design. The purpose of descriptive surveys was to collect detailed and factual information that describes an existing phenomena. The target population of the study was bank personnel in Greece. The purpose of the descriptive survey was to collect detailed and factual information that describes an existing phenomena. This finding may be probably explained by the fact that the higher positions imply greater benefits, autonomy, more creative work etc. Finally, well-educated employees are characterized by the significantly lower satisfaction with their salary. Also as educational level increases the bank employees are willing to find work elsewhere (Spector, 1997). He explained the fact that the higher positions imply greater benefits, autonomy, more creative work etc. Harter, Schmidt and Hayes (2002) showed that a causal model should be developed exploring the generalized path of employee satisfaction-engagement to short-term outcomes. Khan, Jam, Akbar, Khan and Hijazi (2011) clearly indicated that those organizations that have job involvement culture, their employees are more committed with organization than those organizations who do not involve their employees. Sowmya and Panchanatham (2011) revealed that job satisfaction is dependent on supervisor behavior, coworker behavior, pay and promotion, job and working condition and organizational aspects. The employees have significant inclination towards optimistic supervisory behavior and pleasant organizational setup. Bhatti, Nawab and Akbar (2011) claim that investment in employee participation in an organization showed better results, high employees' commitment and productivity, development of desired knowledge, skills, attitudes and other behaviors, which results in higher job satisfaction and organizational performance. Oluwakemi, Michael and Tunde (2011) demonstrated that training is a tool that can assist in building a more committed and productive workforce and can lead to greater commitment and less employee turnover. A study on business-unit-level relationship between employee satisfaction, employee engagement, and business outcomes revealed that most job satisfaction studies have focused on the individual employee level as a 
unit of analysis. For example, studies have found positive linkages between general workplace attitudes and individual performance outcomes. Important outcomes such as customer loyalty, profitability, productivity, employee turnover, and safety variables are typically aggregated and reported at the business-unit level. Job involvement as predictor of employee commitment evidence in the context of Pakistan showed that job involvement has been one of the most effective tools used for increasing employee productivity by enhancing employee participation and commitment (Khan, Jam, Akbar, Khan and Hijazi, 2011). Impact of employee commitment on employee satisfaction role of employee performance as a moderating variable showed that role of employee commitment has always been accepted as an active catalyst for improving organizational satisfaction (Khan, Rehman and Akram, 2012). Every organization should develop strategies that strengthen the work environment and increase the employee morale and employee satisfaction to enhance employee performance and productivity, which ultimately results in high profits, customer satisfaction as well as customer retention (Sageer, Rafat and Agarwal, 2012).

\section{Research Plan and Design}

This study has employed descriptive and causal comparative research designs to deal with the fundamental issues associated with the impact of employee participation on job satisfaction, employee fairness perception and organizational commitment of commercial banks of Nepal.

\section{Nature and Sources of Data}

This study has used the primary data. The primary source of data has been used to assess the opinion of bank's employees regarding the impact of employee participation on job satisfaction, employee fairness perception and organizational commitment of commercial banks in Nepal. The structured questionnaire survey has been conducted to collect and record the opinions and perception of employees regarding impact of employee participation on job satisfaction, employee fairness perception, and organizational commitment. The questionnaires used for the primary survey contain general, tick mark, ranking, five point Likert scale and closed-ended questions designed to assess the impact of employee participation in different selected commercial banks.

\section{Description of the Sample}

Population of this study includes all 32 commercial banks of Nepal. In selecting the most reliable and representative samples, stratified sampling techniques was used. The population of the commercial banks can be stratified as joint ventures, non-joint ventures and public banks. 15 commercial banks were selected as a sample. The selected sample banks and the number of observations have been presented in Table 1. Total number of observations used for this study is 200 which include 70 observations from the joint venture banks, 110 observations from the non-joint venture banks and 20 observations from the public banks. 
Table 1: Summary of sample banks and observations

\begin{tabular}{|c|c|c|c|}
\hline S. No & Strata & Bank & Observations \\
\hline 1 & Joint Venture Banks & Nepal SBI Bank & 10 \\
\hline 2 & & Everest Bank & 20 \\
\hline 3 & & Nabil Bank & 10 \\
\hline 4 & & Himalayan Bank & 10 \\
\hline 5 & & Standard Chartered Bank & 20 \\
\hline 6 & \multirow{8}{*}{$\begin{array}{l}\text { Non-Joint Venture } \\
\text { Banks }\end{array}$} & Sanima Bank Ltd & 20 \\
\hline 7 & & Bank of Kathmandu & 10 \\
\hline 8 & & Prabhu Bank Ltd & 10 \\
\hline 9 & & Machhapuchhre Bank & 10 \\
\hline 10 & & Kumari Bank & 10 \\
\hline 11 & & Laxmi Bank & 10 \\
\hline 12 & & Mega Bank Ltd & 20 \\
\hline 13 & & Global IME Bank Ltd & 20 \\
\hline 14 & \multirow{2}{*}{ Public Banks } & Nepal Bank & 10 \\
\hline 15 & & Agriculture Development Bank & 10 \\
\hline \multicolumn{3}{|c|}{ Total number of observation } & 200 \\
\hline
\end{tabular}

\section{Sampling Technique}

Stratified sampling technique categories the banks in three strata namely joint ventures, non- joint ventures and public banks out of total population of 32 commercial banks. After dividing the population into three strata, 15.63 percent of joint venture banks, 25 percent of non-joint venture banks and 6.25 percent of public banks have been included in the sample based on established period (before 2002/03). Similarly, for the selection of sample respondents, systematic random sampling has been used to select the bank's branches within Kathmandu valley.

\section{Instrumentation}

Primary data were gathered by surveying the bank's employees by using the self-administered survey questionnaire in Likert scale.

\section{Validity and Reliability}

To test the reliability and validity of data Cronbach's alpha $(\alpha)$ is used. The value of Cronbach's alpha was 0.893 on 51 items. 


\section{Results and Discussion \\ Respondents' Demographic Profile}

Out of the 200 questionnaires sent to the potential respondents, 160 valid respondents returned their responses to the questionnaire. Hence, the response rate was eighty percent. All the respondents were the employees of commercial banks inside the Kathmandu Valley. The percentages of male respondents was 48 and that of female respondent was 52. Regarding the age of the respondents, majority of them represented 18-29 years age group. Out of total respondents, 66 percent represents this age group. Similarly, 31 percent respondents were from 30-39 years age group, and 3 percent respondents represented 40-49 age group. It has been found that the number of unmarried respondents is greater than that of married respondents. Single respondents represent 56 percent, and married respondents represent 44 percent of total respondents. Majority of the respondents come under university level category that is 80 percent, and 15 percent respondents comes from college level and 5 percent respondent's comes under high school level. The larger pie represents university level, medium pie represents college level while the smaller pie represents high school level. Majority of the respondents of this study works in customer service department which is 20 percent and 19 percent respondents works in loan. Similarly, 18 percent, 14 percent, 10 percent, 8 percent, 4 percent, 4 percent and 3 percent of respondents work in cash, others, retail, SME, HR management, and corporate department respectively. Majority of the respondents of this study were general staff i.e. 66 percent respondents, and 17 percent respondents work as officers. Similarly, 8 percent respondents work as managers, and 9 percent work in others which includes junior assistant, management trainee, respectively. It has been found that majority of respondents (40\%) had experience of 2-5 years. 25 percent of respondent had the experience of more than five years; respondents having experience of 1 - 2 years were 21 percent; 8 percent of respondents the experience of 1 year, and 6 percent respondents had experience of half year. Majority of the respondents (84\%) had income of Rs. 20,000-30,000 and 8 percent respondents had income of Rs. 30,000 - 40,000. Similarly, 6 percent respondents had income of Rs. 40,000 - 50,000. The respondents with income of 50,000-60,000 and respondent having the salary above 60,000 were both 1 percent.

\section{Employee Participation Practices in Nepalese Commercial Banks}

The ranking questions were prepared and the respondents were requested to fill up the rank according to their perception on participation shown on table 3 . Banks where management gives recognition for job performance has the highest ranking participation which covers mean 3.49 and standard deviation 0.932. It shows organizations give most priority in encouraging employees to perform better job. On the other hand, managers encouraging employees to apply their new abilities and skills in their daily work has the lowest ranking which covers mean 2.78 and standard deviation 1.038. It is given less priority, which shows that employee using their new abilities and skills are less encouraged in organization. 
Table 3: Employee participation practices in Nepalese commercial banks

\begin{tabular}{|c|c|c|c|c|c|c|c|c|c|c|}
\hline Statements & & 1 & 2 & 3 & 4 & 5 & Total & Mean & S.D & Rank \\
\hline $\begin{array}{l}\text { My supervisor asks me for my opinions when } \\
\text { determining my work. }\end{array}$ & $\mathrm{n}$ & 14 & 43 & 34 & 56 & 13 & 160 & 2.9 & 1.053 & XII \\
\hline Highly motivated by work goals. & $\mathrm{n}$ & 0 & 49 & 43 & 60 & 8 & 160 & 3.28 & 0.964 & IV \\
\hline $\begin{array}{l}\text { I feel involved in important decisions in orga- } \\
\text { nization. }\end{array}$ & $\mathrm{n}$ & 10 & 59 & 45 & 40 & 6 & 160 & 2.93 & 1.01 & $\mathbf{X I}$ \\
\hline $\begin{array}{l}\text { Employees affected by decisions are asked for } \\
\text { their inputs. }\end{array}$ & $\mathrm{n}$ & 7 & 26 & 63 & 58 & 6 & 160 & 3.22 & 0.902 & VII \\
\hline $\begin{array}{l}\text { Management gives recognition for job perfor- } \\
\text { mance }\end{array}$ & $\mathrm{n}$ & 9 & 29 & 42 & 69 & 11 & 160 & 3.49 & 0.932 & I \\
\hline I feel free to suggest changes in my job. & $\mathrm{n}$ & 11 & 46 & 32 & 53 & 18 & 160 & 3.42 & 0.987 & II \\
\hline I participate in decision-making & $\mathrm{n}$ & 2 & 57 & 29 & 54 & 18 & 160 & 3.22 & 0.923 & VI \\
\hline I have influence over the division of work & $\mathrm{n}$ & 7 & 59 & 40 & 44 & 10 & 160 & 2.83 & 0.929 & XIV \\
\hline $\begin{array}{l}\text { Employees take action when a problem or op- } \\
\text { portunity arises. }\end{array}$ & $\mathrm{n}$ & 5 & 13 & 38 & 87 & 17 & 160 & 2.97 & 0.945 & $\mathbf{X}$ \\
\hline $\begin{array}{l}\text { Managers encourage employees to apply their } \\
\text { new abilities and skills in their daily work. }\end{array}$ & $\mathrm{n}$ & 3 & 36 & 32 & 57 & 32 & 160 & 2.78 & 1.038 & $\mathbf{X V}$ \\
\hline $\begin{array}{l}\text { Employees' suggestions are seriously taken into } \\
\text { account. }\end{array}$ & $\mathrm{n}$ & 3 & 39 & 58 & 47 & 13 & 160 & 2.89 & 1.025 & XIII \\
\hline I volunteer for activities beyond job requirement. & $\mathrm{n}$ & 2 & 39 & 46 & 57 & 16 & 160 & 3.38 & 1.104 & III \\
\hline $\begin{array}{l}\text { Organization is committed to professional de- } \\
\text { velopment }\end{array}$ & $\mathrm{n}$ & 2 & 26 & 52 & 61 & 19 & 160 & 3.27 & 0.969 & $\mathbf{V}$ \\
\hline Organization is financially stable. & $\mathrm{n}$ & 13 & 18 & 32 & 74 & 23 & 160 & 3.07 & 0.932 & VIII \\
\hline Organization is committed to CSR & $\mathrm{n}$ & 7 & 24 & 43 & 62 & 24 & 160 & 3.01 & 0.971 & IX \\
\hline
\end{tabular}

Source: Field Survey, 2015

\section{Job satisfaction practices in Nepalese Commercial Banks}

The table below shows the response of the employees working in 15 commercial banks of Nepal with the sample size 160. This shows frequency, percentage of respondent, mean and standard deviation. It is measured in five point Likert scales: 1 as very unsatisfied, 2 unsatisfied, 3 don't know, 4 satisfied and 5 very satisfied. Table 4 reveals job satisfaction practices in Nepalese commercial banks. 
Table 4: Job satisfaction practices in Nepalese commercial banks

\begin{tabular}{|l|l|l|l|l|l|l|l|l|l|c|}
\hline Statements & & $\mathbf{1}$ & $\mathbf{2}$ & $\mathbf{3}$ & $\mathbf{4}$ & $\mathbf{5}$ & Total & Mean & S.D & Rank \\
\hline $\begin{array}{l}\text { How satisfied are you with work } \\
\text { conditions? }\end{array}$ & $\mathrm{n}$ & 12 & 55 & 36 & 51 & 6 & 160 & 3.07 & 1.139 & $\mathbf{X I I I}$ \\
\hline $\begin{array}{l}\text { Are you satisfied with work equip- } \\
\text { ment? }\end{array}$ & $\mathrm{n}$ & 3 & 42 & 30 & 78 & 7 & 160 & 3.17 & 0.926 & $\mathbf{X}$ \\
\hline $\begin{array}{l}\text { How satisfied are you with the } \\
\text { task variety in your job? }\end{array}$ & $\mathrm{n}$ & 9 & 47 & 63 & 28 & 13 & 160 & 2.83 & 0.998 & $\mathbf{X V}$ \\
\hline $\begin{array}{l}\text { Do you feel you are valued in your } \\
\text { job? }\end{array}$ & $\mathrm{n}$ & 0 & 41 & 53 & 56 & 10 & 160 & 3.19 & 0.906 & VIII \\
\hline $\begin{array}{l}\text { How satisfied are you with your } \\
\text { immediate supervisor? }\end{array}$ & $\mathrm{n}$ & 3 & 21 & 50 & 67 & 19 & 160 & 3.28 & 1.021 & VII \\
\hline $\begin{array}{l}\text { How satisfied are you with your } \\
\text { immediate supervisor's abilities? }\end{array}$ & $\mathrm{n}$ & 0 & 35 & 46 & 56 & 23 & 160 & 3.13 & 1.155 & XII \\
\hline $\begin{array}{l}\text { Are you satisfied, you don't do } \\
\text { things against your conscience? }\end{array}$ & $\mathrm{n}$ & 0 & 42 & 53 & 53 & 12 & 160 & 3.18 & 1.081 & IX \\
\hline $\begin{array}{l}\text { To what extent does the current } \\
\text { work reflect your abilities? }\end{array}$ & $\mathrm{n}$ & 9 & 53 & 60 & 33 & 5 & 160 & 2.94 & 1.036 & XIV \\
\hline $\begin{array}{l}\text { Are you satisfied with the freedom } \\
\text { in work? }\end{array}$ & $\mathrm{n}$ & 1 & 60 & 51 & 38 & 10 & 160 & 3.61 & 0.897 & I \\
\hline $\begin{array}{l}\text { How satisfied are you with the } \\
\text { banks salary? }\end{array}$ & $\mathrm{n}$ & 13 & 64 & 32 & 47 & 4 & 160 & 3.49 & 1.105 & II \\
\hline $\begin{array}{l}\text { Are you satisfied with banks ben- } \\
\text { efit system? }\end{array}$ & $\mathrm{n}$ & 12 & 54 & 36 & 55 & 3 & 160 & 3.17 & 0.955 & XI \\
\hline $\begin{array}{l}\text { Are you satisfied with your co- } \\
\text { workers do they get along? }\end{array}$ & $\mathrm{n}$ & 12 & 21 & 42 & 64 & 21 & 160 & 3.29 & 0.987 & VI \\
\hline $\begin{array}{l}\text { Are you satisfied with praise for } \\
\text { doing a job? }\end{array}$ & $\mathrm{n}$ & 5 & 32 & 50 & 61 & 12 & 160 & 3.43 & 0.943 & V \\
\hline $\begin{array}{l}\text { Are you satisfied with career ad- } \\
\text { vancement opportunities? }\end{array}$ & $\mathrm{n}$ & 3 & 45 & 60 & 42 & 10 & 160 & 3.48 & 1.121 & III \\
\hline
\end{tabular}

The ranking questions were prepared and the respondent were requested to fill up the rank according to their perception on job satisfaction. Their responses are shown on table 4 where, the question are you satisfied with the freedom in work has the highest ranking which covers mean 3.62 and standard deviation .897 , which shows that employees are satisfied with the freedom given to use their judgment in work. On the other hand, the question, how satisfied are you with the task variety in your job, has the lowest ranking with mean 2.83 and standard deviation .998 , which shows that employee are not satisfied with the task variety that means organization lacks job rotation.

\section{Employee Fairness Perception Practices in Nepalese Commercial Banks}

The table below shows the response of the employees working in 15 commercial banks of Nepal with the sample size 160. This shows frequency, percentage of respondent, mean and standard deviation. It is 
measured in five point Likert scales as 1 strongly disagree, 2 disagree, 3 don't know, 4 agree and 5 strongly agree. Table 5 reveals employee fairness perception practices in Nepalese commercial banks.

The ranking questions were prepared and the respondents were requested to fill up the rank according to their fairness perception in organization as shown on table 5 where, every employee has opportunity to get promotion in bank has the highest ranking, which covers mean 3.33 and standard deviation 1.092, which shows that employees get promoted in bank according to their merit. On the other hand, the question, bank provides equal benefits for every employee, has the lowest ranking, which covers mean 2.41 and standard deviation 1.006, which shows that there is inequality in benefit system in organizations.

Table 5: Employee fairness practices in Nepalese commercial banks

\begin{tabular}{|l|c|c|c|c|c|c|c|c|c|c|}
\hline \multicolumn{2}{|c|}{ Statements } & 1 & $\mathbf{2}$ & $\mathbf{3}$ & $\mathbf{4}$ & $\mathbf{5}$ & Total & Mean & S.D & Rank \\
\hline $\begin{array}{l}\text { Every employee is treated equally in } \\
\text { the bank. }\end{array}$ & $\mathrm{n}$ & 17 & 68 & 49 & 24 & 2 & 160 & 2.54 & 0.917 & IX \\
\hline $\begin{array}{l}\text { I get respect from other employees. } \\
\text { Bank has fair evaluation system. }\end{array}$ & $\mathrm{n}$ & 3 & 43 & 26 & 75 & 13 & 160 & 3.33 & 1.019 & II \\
\hline $\begin{array}{l}\text { Bank manager is fair in } \\
\text { communicating with employees. }\end{array}$ & $\mathrm{n}$ & 11 & 29 & 53 & 54 & 13 & 160 & 3.18 & 1.045 & IV \\
\hline $\begin{array}{l}\text { Same level of employees receives } \\
\text { same salaries. }\end{array}$ & $\mathrm{n}$ & 12 & 38 & 48 & 41 & 21 & 160 & 3.13 & 1.144 & V \\
\hline $\begin{array}{l}\text { Bank exist different work hour for } \\
\text { different employees. }\end{array}$ & $\mathrm{n}$ & 17 & 74 & 36 & 30 & 3 & 160 & 2.55 & 0.976 & VIII \\
\hline $\begin{array}{l}\text { Promotion is fair in bank. } \\
\text { Prom }\end{array}$ & $\mathrm{n}$ & 32 & 51 & 54 & 21 & 2 & 160 & 2.44 & 0.995 & X \\
\hline $\begin{array}{l}\text { Bank provides equal benefits for every } \\
\text { employee. }\end{array}$ & $\mathrm{n}$ & 22 & 83 & 28 & 21 & 6 & 160 & 2.41 & 1.006 & XI \\
\hline $\begin{array}{l}\text { Bank emphasizes fair competition in } \\
\text { workplace. }\end{array}$ & $\mathrm{n}$ & 5 & 23 & 73 & 50 & 9 & 160 & 3.22 & 0.874 & III \\
\hline $\begin{array}{l}\text { Every employee has opportunity to get } \\
\text { promotion in bank. }\end{array}$ & $\mathrm{n}$ & 7 & 31 & 49 & 48 & 25 & 160 & 3.33 & 1.092 & I \\
\hline $\begin{array}{l}\text { Job performance evaluations done by } \\
\text { my supervisor is fair and based on } \\
\text { performance. }\end{array}$ & $\mathrm{n}$ & 10 & 45 & 59 & 29 & 17 & 160 & 2.99 & 1.07 & VI \\
\hline
\end{tabular}

\section{Organizational Commitment Practices in Nepalese Commercial Banks}

The table 6 shows the response of the employees working in 15 commercial banks of Nepal with the sample size 160. This shows the frequency, percentage of respondents, mean and standard deviation. It is measured in five point Likert scales as 1 strongly disagree, 2 disagree, 3 don't know, 4 agree and 5 strongly agree. Table 6 reveals organizational commitment practices in Nepalese commercial banks. 
Table 6: Organizational commitment practices in Nepalese commercial banks

\begin{tabular}{|c|c|c|c|c|c|c|c|c|c|c|}
\hline \multicolumn{2}{|l|}{ Statements } & 1 & 2 & 3 & 4 & 5 & Total & Mean & S.D & Rank \\
\hline $\begin{array}{l}\text { I am willing to put in a great deal of effort } \\
\text { beyond expected in order to help this } \\
\text { organization to be successful }\end{array}$ & $\mathrm{n}$ & 0 & 21 & 20 & 87 & 32 & 160 & 3.81 & 0.906 & I \\
\hline $\begin{array}{l}\text { I talk up this organization to my friends as } \\
\text { a great organization to work for }\end{array}$ & $\mathrm{n}$ & 0 & 25 & 37 & 85 & 13 & 160 & 3.54 & 0.853 & III \\
\hline $\begin{array}{l}\text { I would accept any type of job } \\
\text { assignment in order to keep working for } \\
\text { this organization }\end{array}$ & $\mathrm{n}$ & 3 & 31 & 65 & 49 & 12 & 160 & 3.23 & 0.911 & VI \\
\hline $\begin{array}{l}\text { I find that my values and this } \\
\text { organization's values are very similar }\end{array}$ & $\mathrm{n}$ & 8 & 65 & 43 & 36 & 8 & 160 & 2.82 & 1.002 & IX \\
\hline $\begin{array}{l}\text { I am proud to tell others that I am part of } \\
\text { this organization }\end{array}$ & $\mathrm{n}$ & 6 & 20 & 49 & 66 & 19 & 160 & 3.45 & 0.983 & IV \\
\hline $\begin{array}{l}\text { This organization really inspires the very } \\
\text { best in me. }\end{array}$ & $\mathrm{n}$ & 3 & 53 & 43 & 45 & 16 & 160 & 3.11 & 1.04 & VII \\
\hline $\begin{array}{l}\text { I am extremely glad that I chose this } \\
\text { organization to work for over others }\end{array}$ & $\mathrm{n}$ & 3 & 41 & 35 & 64 & 17 & 160 & 3.32 & 1.03 & $\mathbf{V}$ \\
\hline $\begin{array}{l}\text { I really care about the fate of this } \\
\text { organization }\end{array}$ & $\mathrm{n}$ & 3 & 19 & 43 & 64 & 31 & 160 & 3.63 & 0.988 & II \\
\hline $\begin{array}{l}\text { For me, this is the best of all organization } \\
\text { to work }\end{array}$ & $\mathrm{n}$ & 11 & 53 & 54 & 29 & 13 & 160 & 2.87 & 1.051 & VIII \\
\hline $\begin{array}{l}\text { I would be very happy to spend the rest of } \\
\text { my career with this organization. }\end{array}$ & $\mathrm{n}$ & 9 & 63 & 48 & 29 & 11 & 160 & 2.81 & 1.023 & $\mathbf{X}$ \\
\hline
\end{tabular}

\section{Summary of Dimensions}

The descriptive statistics shows that organizational commitment has the highest mean of 3.26 with standard deviation 0.697 followed by employee participation with mean 3.25 and standard deviation 0.616 , and the variable job satisfaction with mean 3.11 and standard deviation 0.596 is followed by employee fairness perception with lowest mean of 2.91 and standard deviation 0.618 . It shows that compared to fairness perception and satisfaction, employee participation has more impact on organizational commitment. Table 7 shows the descriptive statistics of the variables used in the study.

Table 7: Descriptive statistics

\begin{tabular}{|l|c|c|c|c|c|}
\hline & N & Minimum & Maximum & Mean & Std. Deviation \\
\hline Employee Participation & 160 & 1.80 & 4.80 & 3.25 & .617 \\
\hline Job Satisfaction & 160 & 1.73 & 4.80 & 3.11 & .596 \\
\hline Employee Fairness Perception & 160 & 1.45 & 5.00 & 2.91 & .619 \\
\hline Organizational Commitment & 160 & 1.40 & 4.90 & 3.26 & .697 \\
\hline & & & & & \\
\hline
\end{tabular}




\section{Relationship Between the Variables}

Correlation among employee participation with job satisfaction, employee fairness perception, and organizational commitments are explained in this section of study. Correlation analysis, using Pearson Correlation Coefficient was conducted on all independent and dependent variables. The sample size for this research study was 160 participants. Therefore, it is reasonable to expect some kind of statistically significant relationship among these pairs of variables. Table 8 shows the Pearson Correlation Coefficient between the independent variable employee participation with dependent variables job satisfaction, employee fairness perception and organizational commitment. There is correlation between the independent variable employee participation with dependent variable job satisfaction. This table contains the correlation information needed to answer the first hypotheses of this research study. Here, $p<.01$. It shows significant relationship between employee participation and job satisfaction at 1 percent level, which implies that higher the employee participation higher will be the job satisfaction.

There is correlation between the independent variable employee participation with dependent variable employee fairness perception. This table contains the correlation information needed to answer the second hypotheses of this research study. Here, $\mathrm{p}<.01$. It shows significant relationship between employee participation and employee fairness perception at 1 percent level, which shows higher the employee participation higher will be the fairness perception among employees.

There is correlation between the independent variable employee participation with dependent variable organizational commitment. This table contained the correlation information needed to answer the third hypotheses of this research study. Here, $p<.01$. It shows significant relationship between employee participation and organizational commitment at 1 percent level, which further implies higher the employee participation higher will be the organizational commitment.

Table 8: Pearson correlation coefficient

\begin{tabular}{|c|c|c|c|c|c|}
\hline & & $\begin{array}{l}\text { Employee } \\
\text { Participation }\end{array}$ & $\begin{array}{c}\text { Job } \\
\text { Satisfaction }\end{array}$ & $\begin{array}{l}\text { Employee } \\
\text { Fairness Perception }\end{array}$ & $\begin{array}{l}\text { Organiza- } \\
\text { tional Com- } \\
\text { mitment }\end{array}$ \\
\hline \multirow{2}{*}{ Employee Participation } & $\mathrm{r}$ & 1 & & & \\
\hline & $\mathrm{N}$ & 160 & & & \\
\hline \multirow{2}{*}{ Job Satisfaction } & $\mathrm{r}$ & $.690^{* *}$ & 1 & & \\
\hline & $\mathrm{N}$ & 160 & 160 & & \\
\hline \multirow{2}{*}{ Employee Fairness Perception } & $\mathrm{r}$ & $.637^{* *}$ & $.678^{* *}$ & 1 & \\
\hline & $\mathrm{N}$ & 160 & 160 & 160 & \\
\hline \multirow{2}{*}{ Organizational Commitment } & $\mathrm{r}$ & $.718^{* *}$ & $.701^{* *}$ & $.638^{* *}$ & 1 \\
\hline & $\mathrm{N}$ & 160 & 160 & 160 & 160 \\
\hline
\end{tabular}

**. Correlation is significant at the 0.01 level (2-tailed). 


\section{Conclusion}

The major conclusion of this study is that the impact of employee participation on job satisfaction, employee fairness perception and organizational commitment have positive significant relation. Among all three determinants organizational commitment is more influenced by employee participation as it has highest correlation coefficient. The most of the surveyed employees agreed that management gives recognition for job performance and they are satisfied with the freedom in work, every employee has opportunity to get promotion in bank, and they are willing to put in a great deal of effort beyond expected in order to help the organization to be successful.

Based on the findings of the study, it can be concluded that much awareness is required in the area of employee's involvement in organizational decision making. The three research hypotheses were formulated and tested to test the relationship, and the result showed positive significant relationship and rejected all three null hypotheses. Likewise, it can also be concluded that the employees of Nepalese commercial banks are highly motivated by employee participation.

\section{References}

Agrawal, G. R. (2005). Organizational relation in Nepal. Kathmandu: M.K. Publisher and Distributor. Allen, N, and Meyer, J. (1991). A three component conceptualization of organizational commitment. Human Resource Management Review, 1. 64-89.

Argyris, C. (1964). Integrating the individual and the organization. New York: Wiley.

Bhatti, K. K., Nawab, D. S. and Akbar, D. A. (2011). Effect of direct participation on organizational commitment. International Journal of Business and Social Science, 2(9), 15-23.

Fenton-O'Creevy, M. (2001).Middle Managers: Their contribution to employee involvement. Journal of Human Resource Management, 11(1), 24-40.

Harter, J. K., Schmidt, F. L. and Hayes, T. L. (2002). Business-unit-level relationship between employee satisfaction, employee engagement, and business outcomes: A meta-analysis. Journal of Applied Psychology, 87(2), 268-279.

Hussain, H. (2010). Evidence on structure conduct performance hypothesis in Pakistani commercial banks. International Journal of Business and Management 5(9), 174-187.

Ketchand, A., and Strawser, J. (2001). Multiple dimensions of organizational commitment: Implications for future accounting research. Behavioral research in accounting 13(1), 221-251.

Khan, D. M., Rehman, Z. and Akram, M. W. (2012). The impact of employee commitment on employee satisfaction role of employee performance as a moderating variable.Singaporean Journal of Business Economics, and Management Studies, 1(2), 85-167.

Khan, T. I., Jam, F. A., Akbar, A., Khan, M. B. and Hijazi, S. T. (2011). Job involvement as predictor of employee commitment. International Journal of Business and Management, 6(4), 252-262.

Mathieu, J., and Zajac, D. (1990). A review and meta-anlaysis of the antecedents, correlates, and consequences of organizational commitment. Psychological Bulletin, 108(2), 171-194. 
Newstrom, J., and Davis,K. (2004). Organizational behavior, human behavior at work. New Delhi: Tata Mcgraw- Hill Company Limited.

Oluwakemi, A. O., Michael, O. and Tunde, E. (2011). Enhancing employees' commitment to organisation through training. International Journal of Business and Management, 6(7), 280-286.

Pant, P. R. (2009). Principles of management. Kathmandu: Buddha Academic Publisher and Distributer.

Sageer, A., Rafat, D. S. and Agarwal, M. P. (2012). Identification of variables affecting employee satisfaction and their impact on the organization.IOSR Journal of Business and Management, 5(1), 32-39.

Sowmya, K. R., and Panchanatham, N. (2011). Factors influencing job satisfaction of banking sector employees in Chennai, India. Journal of Law and Conflict Resolution 3(5), 76-79.

Spector, P. (1997). Job Satisfaction: Application, Assessment, Cause and Consequences. London: Sage Publications.

Tang, T., and Sarsfield-Baldwin, L. (1996). Distributive and procedural justice as related to satisfaction and commitment. SAM Advanced Management Journal, 61(3), 25-31. 